\title{
TOPICAL ISSUES OF RESEARCH AND EDUCATIONAL POLICY DEVELOPMENT IN RUSSIA
}

\author{
QUESTÕES TÓPICAS DE PESQUISA E DESENVOLVIMENTO DE POLÍTICA \\ EDUCACIONAL NA RÚSSIA
}

\section{CUESTIONES DE TEMA DE LA INVESTIGACIÓN Y EL DESARROLLO DE POLÍTICAS EDUCATIVAS EN RUSIA}

DOI: $10.22481 /$ rbba.v1i02.7698

R.A. Vdovin

Samara National Research University, Russia Orcid: http://orcid.org/0000-0001-8835-2999

E-mail: vdovin.ssau@mail.ru

A.I. Rozentsvaig Samara National Research University, Russia Orcid: http://orcid.org/0000-0001-8425-4240

E-mail: lawyeranna@mail.ru

\begin{abstract}
The article deals with some directions of the research and educational policy development. The correlation of approaches to the development of the strategic academic leadership program and the world-class research and educational centers establishing, centers of competence development is analyzed. Engineering knowledge and technology are at the heart of the modern economy. Engineering methods, approaches, and technologies have permeated medicine, biology, agriculture, chemistry, and the development of new materials. Understanding the directions of technological development determines the prospects for creating and using new products. further development of the issue related to the introduction of artificial intelligence technologies in the engine-building industry from
\end{abstract}


the point of view of legal regulation will allow to consolidate the official legal status of such technologies at the legal level and regulate the algorithm and delimit the use of artificial intelligence technologies. The analysis of responses to the big challenges of scientific and technological development and the exhaustion of economic growth opportunities, the formation of the digital economy and the risks of reducing human resources. The development of international accreditation procedures is proposed.

Keywords: Research; Education: Research and educational center: Competence development center; Artificial intelligence technologies: International accreditation.

\section{RESUMO}

$\mathrm{O}$ artigo trata de algumas direções do desenvolvimento de pesquisas e políticas educacionais. Analisa a correlação de abordagens para o desenvolvimento do programa de liderança acadêmica estratégica e os centros de pesquisa e educação de classe mundial que estabelecem centros de desenvolvimento de competências. O conhecimento e a tecnologia de engenharia estão no centro da economia moderna. Métodos de engenharia, abordagens e tecnologias têm permeado medicina, biologia, agricultura, química e desenvolvimento de novos materiais. Entender os rumos do desenvolvimento tecnológico determina as perspectivas de criação e utilização de novos produtos. O desenvolvimento adicional relacionado à introdução de tecnologias de inteligência artificial na indústria de construção de motores, desde o ponto de vista da regulação jurídica, permitirá consolidar o status legal dessas tecnologias e regular o algoritmo e delimitar o uso de tecnologias de inteligência artificial. A análise das respostas aos grandes desafios do desenvolvimento científico e tecnológico e o esgotamento das oportunidades de crescimento econômico, a formação da economia digital e os riscos de redução dos recursos humanos. Propõe-se o desenvolvimento de procedimentos internacionais de acreditação.

Palavras-chave: Pesquisa; Educação; Pesquisa e centro educacional; Centro de desenvolvimento de competências; Tecnologias de inteligência artificial; Acreditação internacional.

\section{RESUMEN}

El artículo trata sobre algunas orientaciones para el desarrollo de políticas de investigación y educación. Se analiza la correlación de enfoques para el desarrollo del programa de liderazgo académico estratégico y los centros de investigación y educación de clase mundial que establecen, centros para el desarrollo de competencias. El conocimiento y la tecnología de la ingeniería están en el corazón de la economía moderna. Métodos, enfoques y tecnologías de ingeniería han permeado la medicina, la biología, la agricultura, la química y el desarrollo de nuevos 
IN RUSSIA

materiales. Comprender la dirección del desarrollo tecnológico determina las perspectivas de crear y utilizar nuevos productos. El mayor desarrollo del tema relacionado con la introducción de tecnologías de inteligencia artificial en la industria de la construcción de motores desde el punto de vista de la regulación legal, permitirá consolidar el estatus oficial de estas tecnologías y regular el algoritmo y limitar el uso de tecnologías de inteligencia. artificial. El análisis de respuestas a los grandes desafíos del desarrollo científico y tecnológico y el agotamiento de oportunidades de crecimiento económico, la formación de la economía digital y los riesgos de reducción de recursos humanos. Se propone desarrollar procedimientos de acreditación internacional.

Palabras clave: Investigación; Educación; Centro de investigación y educación; Centro de desarrollo de habilidades; Tecnologías de inteligencia artificial; Acreditación internacional.

\section{INTRODUCTION}

Today, the speed of technological change in the world is increasing many times, and we have to create our own technologies and standards in the areas that determine the future [1]. In a message to the Federal Assembly on January 15, 2020 President of the Russian Federation Vladimir Putin emphasized that the labor market is changing dynamically today, new professions are constantly emerging, requirements for existing ones are becoming more complex, and higher education should respond flexibly and quickly to these requests. Attention is drawn to the need to allow students after the second year to choose a new direction or program of study, including related professions. Of particular importance in this case is the provision of freedom for work, scientific and innovative search.

The development of responses to the big challenges of scientific and technological development and in terms of exhausting the opportunities for economic growth, the formation of the digital economy and the risks of reducing human resources is of particular relevance.

Engineering knowledge and technology are at the heart of the modern economy. Engineering methods, approaches, and technologies have permeated medicine, biology, agriculture, chemistry, and the development of new materials. Understanding the directions of technological development determines the prospects for creating and using new products.

\section{DISCUSSION}

Revista RBBA Revista Binacional Brasil Argentina 
IN RUSSIA

New special legal regimes are of particular importance in this regard. The first steps to establish special regulation in order to create the necessary conditions for the development and implementation of artificial intelligence technologies were taken in the subject of the Russian Federation - the Federal city of Moscow from July 1, 2020 in accordance with Federal law № 123-FZ of April 24, 2020.

The key objectives of establishing an experimental legal regime are:

- to improve the quality of life of the population;

- improving the efficiency of state or municipal management;

- improving the efficiency of business entities in the implementation of artificial intelligence technologies;

- formation of a comprehensive system for regulating public relations that arise in connection with the development and use of artificial intelligence technologies, based on the results of establishing an experimental legal regime.

The main objectives of establishing an experimental legal regime are:

- creating favorable legal conditions for the development of artificial intelligence technologies;

- testing of artificial intelligence technologies and results of its application;

- evaluation of the effectiveness and efficiency of establishing special regulation based on the results of establishing an experimental legal regime.

Important principles for establishing an experimental legal regime are:

- transparency of the legal regime of the experimental;

- protection of human and civil rights and freedoms, ensuring the security of the individual, society and the state;

- non-discriminatory access to the results of the use of artificial intelligence.

Due to the rapid development of artificial intelligence technologies in various industries, its legal regulation within the legal aspects of the current legislation is becoming important. First of all, this applies to the branches of the military-industrial complex, for example, engine building, since these industries are the most vulnerable and often undergo modernization in terms of compliance with the development of world science and technology.

Currently, increasingly there is information about the use of artificial intelligence in manufacturing: for example, this technology, based on algorithms of neural network analysis is used for optimization of process parameters of various manufacturing processes of high 
IN RUSSIA

precision, - critical parts of gas turbine engines and the choice of the most rational combinations to obtain the final product of the required quality and with minimum costs.

In particular, foundry specialists are constantly faced with the problems of determining the optimal parameters of the technological process in order to minimize the cost of manufacturing the casting (maximum yield) and minimize the percentage of casting defects. These goals are in a certain contradiction: for example, profits, refrigerators increase the quality of casting, but reduce the percentage of yield. In addition, there are difficulties with the presence of a large number of factors that affect the possibility of different types of casting defects in different ways. The main problem is the complexity of formalizing the problem of optimizing the technological process of casting production.

Often, the solution to this problem is based on the experience of technologists and has a heuristic character. There are also systems aimed at automating individual stages of solving this problem. Here you can distinguish universal systems (modeling of foundry processes, designing elements of foundry equipment, etc.) and specialized software products aimed at solving one specific unique problem. The latter differ, as a rule, in deep mathematical elaboration and accuracy of the results obtained. The first ones are successfully applied at the stage of process design, but they have limitations on the factors taken into account and the relationships between them, as well as restrictions related to the requirements for completeness and clarity of information. For this reason, it is not possible to use such software tools for making operational technological decisions. Such decisions are made based on the experience of technologists, among whom there is a shortage of highly qualified specialists.

Obviously, the urgent task for the near future is to attract new information technologies and develop a software and methodological complex that covers the entire range of problems related to the design of the technological process of casting production. The development of such a complex based on the integration of mathematical models, expert experience, a base of heuristic techniques, artificial intelligence tools and unique information and methodological materials is an urgent scientific and practical task.

Thus, further development of the issue related to the introduction of artificial intelligence technologies in the engine-building industry from the point of view of legal regulation will make it possible to consolidate the official legal status of such technologies at the legal level and regulate the algorithm and delimit the area of use of artificial intelligence technologies.

Revista RBBA $\mid$ Revista Binacional Brasil Argentina 
IN RUSSIA

In this regard, the development of the Institute of international accreditation is also an urgent requirement of the time. The current state accreditation procedure ensures a high level of content and quality of education, but its implementation is not based on national legislation. At the same time, globalization requires evaluating an educational organization in accordance with internationally proven quality standards and obtaining international accreditation. Indicators related to the passage of international accreditation are included in the Federal project "Export education" national project "Education", in monitoring the effectiveness of universities by the Ministry of science and higher education of the Russian Federation annually and aims.

International accreditation plays an important role in ensuring the global competitiveness of Russian universities, which is the main idea of the unified state support program for at least 100 higher education institutions of the Russian Federation - the strategic academic leadership Program (hereinafter referred to as PSAL), which starts from 2021. PSAL concentrates resources to ensure the contribution of universities to achieving the national goal and fulfilling the instructions of the President of the Russian Federation in terms of increasing the scientific and educational potential of higher education institutions and scientific organizations, as well as ensuring the participation of higher education organizations in the socio-economic development of the Russian Federation's subjects. As part of the selection process, projects of University development programs (programs) developed over a ten-year period are evaluated. The achievement of performance indicators by universities should ensure an increase in the contribution of universities to the industry and (or) regional economy; attracting applicants, students and postgraduates who have shown outstanding abilities; implementing adaptive, practice-oriented and flexible educational programs of educational programs and networking with leading Russian and foreign organizations; building research capacity; improving the resource availability and diversification of the University's income structure; building human resources; support for young scientists; improving the efficiency of the University management system.

One of the export indicators of the PSAL project is the share of its participant's students in higher education programs that have current international accreditation from the total number of students in higher education programs.

In this regard, the unified national project in the field of higher education and science for 2021-2030 - "Science and Universities", which is being developed by the Ministry of science and higher education of the Russian Federation, is of particular value. It assumes the

Revista RBBA $\mid$ Revista Binacional Brasil Argentina 
IN RUSSIA

achievement by 2030 of the national goal "Opportunities for self-realization and talent development" to ensure the presence of the Russian Federation among the top ten countries in the world in terms of research and development, including through the creation of an effective higher education system.

It is also necessary to note separately the integrated approach to the normative legal acts being developed in this area.

Thus, by the decree of the Government of the Russian Federation of April 30, 2019 № 537 "on measures of state support for world-class scientific and educational centers based on the integration of higher education organizations and scientific organizations and their cooperation with organizations operating in the real sector of the economy" [2] approved the rules for granting grants in the form of subsidies from the Federal budget for state support of world-class scientific and educational centers based on the integration of higher education organizations and scientific organizations and their cooperation with organizations operating in the real sector of the economy.

By order of the Minister of science and higher education of the Russian Federation № 1227 of September 23, 2020, the criteria for selecting programs for world-class research and educational centers were approved [3]. The first group includes criteria that characterize the research, economic (innovative), human resources and infrastructure potential of a world-class research and education center; the second group includes criteria that characterize the involvement of a subject of the Russian Federation in the implementation of the center's program of activities; the third category includes criteria that characterize the scientific and technological potential of a constituent entity of the Russian Federation in accordance with the spatial development Strategy of the Russian Federation for the period up to 2025, approved by decree of the Government of the Russian Federation № 207-R of February 13, 2019 [4].

Analyzing the selection criteria, as well as approaches to performance indicators of University development programs and programs of world-class research and educational centers, we can assume their correlation in a number of ways, which confirms their strategic importance.

The key cross-cutting focus of the center's work is modern engineering science and technology, which is cross-sectoral and interdisciplinary in nature. They are based on: intellectualization of engineering through the creation of engineering knowledge bases and the development of models, methods and algorithms of "Artificial intelligence", including the 
IN RUSSIA

management of groups (swarms) of Autonomous "smart things" and the creation of digital ecosystems and colonies of such collective intelligence systems; transfer of engineering methods and model solutions between different areas of knowledge; development of the concept of "strong intelligence" for solving complex engineering problems at all stages of the life cycle of complex products; formation of a system of cooperation with Russian and foreign centers on modern engineering. The key competitors of the "Engineering of the future" REC in the world are such centers as Canada Digital Technology Supercluster (an example of a cross - industry engineering center specializing in mechanical engineering and medicine), Saclay Plateau Research and Innovation Cluster (R\&D divisions of technology companies that compete with industrial holdings represented in the Samara REC), aerospace Research \& Innovation Center AbuDhabi (an example of a new generation center with plans for the development of engineering science for several decades to come), pole of competitiveness Cara in French Lyon (center for mobility technologies, automotive industry and transport of the future), RWTH Innovation center in Germany Aachen (example of the innovation center on campus with experience in the successful creation of engineering products for new markets, including the electric car, electroanal, etc.), scientific-educational center rolls-Royce (RollsRoyce) (example of integration of the Corporation, is a world leader in aviation engine building, in the world scientific-educational network of 29 research centers in leading universities), the Berlin center of materials and energy Helmholtz (center, combining a research infrastructure of Germany in the field of materials science), the company AirLiquid (scientific and industrial Association of companies in France for the production of gases for industry, health and environmental protection), the research company Hydrogenics Europe N. V. (intelligence, etc.) is the core of similar innovation centers in the world. These centers are designed in such a way that they do not have one industrial specialization. As a rule, their activities are based on the transfer of engineering solutions between different industries. Therefore, the participants of such centers include both industrial and medical enterprises, as well as organizations of the agro-industrial complex. The transfer of engineering solutions at the intersectoral level has become possible thanks to the development of big data and the artificial intelligence industry-the key competencies of the center.

Belgian scientific and industrial company for the development of installations for the production of hydrogen). 
IN RUSSIA

Analysis of competitors ' activities shows that engineering (including engineering science, applied engineering, industrial artificial

The center has three major segments: advanced industrial engineering (primarily engine building, including hydrogen technologies, as well as green chemistry and materials), engineering of intelligent control systems (primarily production and transport systems, project management, management of self-organizing groups (swarms), as well as smart agriculture and precision farming), engineering of new generation biotechnical systems (in medicine, social sphere, etc.). All of them are aimed at the development and wide application of artificial intelligence models, methods and algorithms as a tool for effective transfer of accumulated engineering knowledge between different high-tech sectors and creation of intelligent decisionmaking systems for managing advanced engineering products.

One of the key target products of the center's activities are: 1. new generation Engines: hybrid, alternative fuel and energy sources, with low environmental load, including new generation rotary-blade units, methane hybrid for cars, diesel locomotives and marine diesel generators. 2. a Series of digital systems for a wide range of engineering projects: a digital engine building platform; a tool platform for building systems based on digital twins, knowledge bases and multi-agent technologies; unified information system for accounting, control and monitoring of railway junctions and intersections; systems for monitoring and managing complex technological objects using ultra-fast radio frequency identification technology; digital platforms and smart service ecosystems. 3. high-Tech products for the space industry: high-orbit transport systems and vehicles, their dynamic, functional and structural elements for building a multi-level monitoring system; small SPACECRAFT, nanosatellites and their groupings with various types of target equipment their dynamic and functional elements, coupled computer optics and image processing systems; unmanned aircraft systems, their dynamic and functional elements for building and functioning a multi-level monitoring system. 4. high-Tech products for the transport industry: Adaptive special equipment on a combined course based on the KAMAZ platform; electric-driven vehicles and an intelligent platform for them; advanced materials and digital counterparts of materials and technological processes for their processing. 5. Digital control system in agriculture (agrodiversity): intelligent cyber-physical control system for precision agricultural enterprises based on the" digital twin " of plants; transport and technological robots; combined navigation and control. 6. Biomedical engineering technologies: software and hardware complexes, services and systems 
IN RUSSIA

for supporting medical decision-making; models of individual treatment and rehabilitation. 7 . hydrogen energy Technologies: hydrogen generation and storage units; small-sized autothermal reforming units; new-generation membrane gas purification reactors; mobile power plant for hydrogen storage; fuel cells. 8. artificial intelligence Products: digital ontology of the use of artificial intelligence tools in research and forecasting of physical, chemical and biological processes; cross-disciplinary digital intelligent systems and educational and methodological complexes for studying, modeling and programming dynamic processes and open systems: Earth and near space, transport and new mobility, alternative energy, Genesis of materials, human and ecosystems.

The center is being created as an effective mechanism for implementing the strategy of scientific and technological development of the Russian Federation at the regional level, capable of finding answers to major challenges and ensuring the implementation of the priorities of scientific and technological development of the country within the framework of the activities chosen by the center.

The tasks of the center are defined as:

1. Organization of world-class advanced research and development in the areas of the center's activities.

2. Attraction to the region, identification and training of talents, highly qualified specialists and technological entrepreneurs (in new practice-oriented educational formats) in the areas of the center's activities.

3. Entering global markets and implementing an extraterritorial model of the center with an ever-growing innovation ecosystem.

One of the key challenges facing the economy of the Russian Federation and the global economy as a whole is the transition to new mobility, which provides for high - quality movement of passengers and cargo with increased efficiency indicators with minimal impact on the environment. In addition, the development of new mobility is inextricably linked with the formation of new markets, without participation in the development of which it is impossible to meet the second challenge - the exhaustion of traditional opportunities for economic development of the Russian Federation. Both challenges (the transition from extensive economic development and the development of new mobility, including the need for effective space development) correspond to the challenges of the Russian Federation's science and technology development Strategy. In General, the current volume of global markets for the 
IN RUSSIA

presence of the center's participants is about $\$ 1$ trillion. On some of them, participants of the center in the horizon of 7-10 years will be able to take a share of 3-5\%. The core markets for the center are the markets for transport systems and new mobility, including the markets for new generation engine technologies (hybrid, electric engines, as well as decarbonization technologies - alternative fuels, environmentally friendly materials), transport management platforms and other technological objects, unmanned technologies, aerospace technologies, digital tools, etc. At the same time, the center's activities are also focused on participation in the markets of new engineering competencies (engineering of living systems, advanced medical technologies, new materials of wide application, etc.).

The development of modern transport systems markets and new mobility is based on three areas: advanced propulsion systems; alternative fuels; and transport management systems. It is in this area that the Samara region, which is the core of the center being formed, has competencies recognized at the world level. Changes in engine production create an image of the future economy. This includes the ability of the economy to achieve the desired level of reducing the environmental burden, the ability to provide a new quality of life and activity for the population (for example, engines for high-speed communication), and the ability to provide significant growth in labor productivity (for example, engines for unmanned systems). The Russian Federation's competitiveness in the global economy will depend on its success in this area. Today, transport systems are under pressure from new trends in the global economy [5]. The 2020 crisis can only increase these challenges. Among them:

- trend 1: lower consumption of hydrocarbon fuels through the electrification of engines, including the transition to hybrid and fully electric engines, etc.

- trend 2: the reduction of emissions of harmful substances and greenhouse gas emissions (primarily sulfur and nitrogen oxides) due to the use of alternative fuels, first of all, the transition to hydrogen fuel, methane and other species;

- trend 3: increasing the efficiency and reducing the safety of transport complex management, primarily through the transition to unpopulated technologies, the introduction of artificial intelligence, multi-agent systems, and other areas;

- trend 4: development of space and air space to improve the human environment. 
IN RUSSIA

In addition to the markets of mobility, members of the center have serious expertise for the development of markets for new engineering competences, which in the programme of activities of the centre related markets of advanced production technology, and markets technologies in modern medicine and several others.

The presence of medical specialization projects is due to the fact that one of the key trends in the development of engineering science around the world today is the flow of knowledge from the field of mechanical engineering from mechanical engineering to the biotechnological sector of living systems engineering (biotech engineering). Such centers of mechanobiology are being created all over the world today, and the center is no exception. In this regard, the use of mechanical engineering technologies in the design of biochips, bone tissues, solving agricultural issues and other areas of living systems is an objectively justified activity of the center.

In General, it is the cross-sectoral and interdisciplinary transfer of knowledge and competencies that should become one of the triggers for the development of science and education in the partner regions and for the implementation of the center's program.

Movement in the center's areas of activity involves overcoming technological barriers, which were discussed in the section of the center's program of activities "Target model". Each technological barrier is a set of innovative challenges that can only be met by being competitive in the global research agenda.

Each of the activities of the center is characterized by its own research agenda, which is aimed at embedding the program of the center's activities. In particular, for the direction of engine systems, the research agenda is formed by trends in the electrification of engines, improving the efficiency of internal combustion engines, switching to alternative fuels, the development of new materials, and the introduction of related technologies and developments.

The research agenda in the field of "Artificial intelligence in engineering "is currently related to the development of new classes of models, methods and algorithms for solving complex engineering problems, building knowledge bases and multi-agent technologies, developing the concept of" strong intelligence " and building digital ecosystems of collective intelligence. Given the rapid progress of this topic abroad, it is of particular importance to create a domestic open "factory" -a tool platform for mass production of intelligent systems for managing enterprises in industry, transport, supply chains, and others, personalized by creating knowledge bases and digital counterparts.

Revista RBBA Revista Binacional Brasil Argentina 
IN RUSSIA

The research agenda in the field of transport systems is determined by the transition to highly and fully automated technologies, smart control systems, including automated management of the UAV fleet, the development of micro-mobility technologies, and the introduction of end-to-end transport management platforms.

Research agenda in the sectors of new engineering competencies (especially health systems) is determined by the mass use of digital technology in medicine and engineering techniques in medicine, including the development of Internet of things medicine, XaaS platforms, different functionality, remote medicine, new diagnostic technologies, the transition to a new generation of drugs, trends in the number of epidemics, ageing populations and many other factors.

All these aspects will be taken into account and worked out at a more detailed level. Including in the framework of the comprehensive research programs, and integrated scientifictechnical programs will be updated of the latest trends, challenges and threats of development of individual sectors, the roadmap, the joint movement center participants.

In cases where the center will lack the competencies to respond to a particular challenge, a decision will be made to create targeted alliances or consortia.

Already, we can say that the probability of consortia is high in such areas as hybrid and electric motors, smart materials in medicine, new materials in mechanical engineering, digital platforms of wide application and artificial intelligence systems for solving engineering problems in industry, transport, agriculture, etc.

In addition, it provides for the formation of competence development centers for managers of scientific, scientific and technical projects and laboratories on the basis of RECs (hereinafter - In order to ensure a systematic approach to the training of personnel necessary for the creation of scientific laboratories and competitive project groups of REC participants and other interested organizations in various regions of Russia, to attract leading scientists and teachers of REC, as well as other highly qualified experts from the Russian and foreign research and scientific-industrial sphere to improve the quality of management training, necessary to increase the competitiveness of the REC participants ' developments and their implementation in the real sector of the Russian economy and on the world market.

Thus, the competence development Center for managers of scientific, scientific and technical projects and laboratories of the scientific and educational center "Engineering of the future" (hereinafter-REC) is created in accordance with paragraph 1.3. The Federal project 
IN RUSSIA

"development of human resources in the field of research and development", the National project "Science", to assist REC participants in forming a systematic approach to the training and professional growth and development of scientific and scientific-pedagogical personnel, providing conditions for scientists to carry out engineering research, research and development, the creation of scientific laboratories and engineering centers.

The REC CRC has two key goals:

1. Development of the scientific staff of the REC of competencies that allow to effectively solve the tasks of the REC Program (organization of world-class advanced research and development; attraction to the region, identification and training of talents, highly qualified specialists and technological entrepreneurs; access to global markets and implementation of the extraterritorial model of the center with an evergrowing innovation ecosystem);

2. Training motivated leaders and world-class teams to implement complex REC projects and find answers to big challenges.

\section{CONCLUSION}

Based on the results of the above-mentioned activities, as well as through a comprehensive assessment of the business, professional and personal qualities of trained personnel, a reserve of scientific and pedagogical staff of the new generation will be formed. In the future, the personnel reserve will be used to form the management team of large scientific, scientific and educational scientific and technical projects (including interdisciplinary ones) at the meta-level. This will also require appropriate confirmation at the international level, one of the ways of which is to pass international accreditation.

\section{REFERENCES}

1. Message of the President of the Russian Federation to the Federal Assembly of January 15, 2020. Reference and legal system "ConsultantPlus".

2. Decree of the Government of the Russian Federation № 537 of April 30, 2019 "On measures of state support for world-class scientific and educational centers based on the integration of higher education organizations and scientific organizations and their cooperation with organizations operating in the real sector of the economy". Reference and legal system "ConsultantPlus".

Revista RBBA Revista Binacional Brasil Argentina 
IN RUSSIA

3. Order of the Minister of science and higher education of the Russian Federation dated September 23, 2020 № 1227 "on approval of criteria for selecting programs of activity of worldclass scientific and educational centers". Reference and legal system"ConsultantPlus".

4. Decree of the Government of the Russian Federation of February 13, 2019 № 207-R "On approval of the strategy of spatial development of the Russian Federation for the period up to 2025". Reference and legal system "ConsultantPlus".

5. Program of activity of the world-class scientific and educational center "Engineering of the future" (the program is not published yet). 